\title{
Multikulturalizam u europskom kontekstu: dosezi i nesuglasja
}

\author{
DOI: https://doi.org/10.11567/met.32.3.3 \\ UDK: 316.72(4) \\ 304.42 \\ Pregledni rad \\ Primljeno: 07. 02. 2017. \\ Prihvaćeno: 24. 02. 2017.
}

\section{Snježana Gregurović}

Institut za migracije i narodnosti, Zagreb

snjezana.gregurovic@imin.hr

\section{SAŽETAK}

U radu se bavi normativnim značenjem multikulturalizma i idejom promicanja kulturne različitosti putem politika identiteta, politika različitosti i politika priznavanja te multikulturalističkim politikama kao odgovorima na izazove povezane s kulturnim i religijskim različitostima. Iznošenjem triju multikulturnih teorija - liberalnog multikulturalizma, egalitarnog multikulturalizma i dijaloškog multikulturalizma i njihovom kritikom želi se upozoriti na ograničene dosege i nesuglasja u vezi s načinima uključivanja različitih kulturnih skupina u društvo. Da bi se upozorilo na propuste multikulturalističkih politika u integraciji migranata, raspravlja se o kritici multikulturalizma iz aspekta političkih lidera Njemačke, Velike Britanije i Francuske, povezanosti etničke različitosti, multikulturalizma i socijalne države te o integracijskim učincima multikulturalističkih politika u zemljama s izdašnom socijalnom državom. Na kraju se predlažu napuštanje jednodimenzionalnog shvaćanja multikulturalizma i uvođenje pristupa koji će u sebi objediniti politiku ekonomske redistribucije i politiku priznavanja različitosti.

KLJUČNE RIJEČI: multikulturalizam, multikulturalističke politike, liberalizam, imigranti, socijalna država, integracijski učinci, europske zemlje

\section{UVOD}

Uz globalizaciju multikulturalizam se nameće ključnim u razumijevanju i objašnjavanju suvremenih liberalnih društava i njihovih obilježja. Sva moderna društva suočavaju se s multikulturnim izazovima čak i kada multikulturalizam nije relevantna tema u društvu, a još manje predstavlja službenu politiku. Multikulturalizam poput nekoga krovnog pojma pokriva puno različitih ideja i iako ne postoji konsenzus u teoriji, napose političkoj filozofiji, o značenju samog termina, ono se najčešće tiče načina razumijevanja i pružanja odgovara na izazove povezane s kulturnim i religijskim 
različitostima. $S$ jedne ga se strane upotrebljava da bi se opisala činjenica društvene različitosti u sociokulturnom i demografskom smislu, dok se s druge naglašava njegovo normativno značenje koje je povezano s promicanjem tolerancije i kulturne različitosti putem politika identiteta, politika različitosti i politika priznavanja.

Kad je o europskim zemljama riječ, multikulturalističke politike kao vrsta integracijskih politika tiču se načina na koje zemlje odgovaraju na različitosti nastale zbog povećanja migrantske populacije. Odgovori zemalja na te različitosti ovise o organizaciji i ustrojstvu državnih institucija, raspodjeli moći i vlasti te načinu funkcioniranja socijalne države (Geddes, 2003). Svaka integracijska politika, pa tako i multikulturalistička, trebala bi težiti tomu da useljenici postanu jednakopravni građani te da s ostatkom društva budu povezani osjećajem zajedničke pripadnosti. U radu se propituje u kojoj mjeri multikulturalističke politike u europskim zemljama uspijevaju ostvariti taj cilj.

Multikulturalizam tj. multikulturalističke politike u europskom su kontekstu doživjele napade s raznih strana. Napad koji je najviše odjeknuo u javnosti onaj je političkih lidera triju ekonomski najmoćnijih europskih država koje su ujedno i zemlje primateljice velikog broja migranata. Njihova osuda multikulturalizma uglavnom se tiče slabih integracijskih učinaka multikulturalističkih politika, ali i razjedinjavanja društva zbog inzistiranja na posebnosti kultura različitih etničkih skupina. Takvo shvaćanje implicira vrlo statičan koncept društvenog poretka u kojemu su kulturne različitosti latentno razdorne i kao takve prijetnja su društvenom jedinstvu. Kako se $u$ novije vrijeme sve više problematizira povezanost politika priznavanja kulturne različitosti s reprodukcijom nejednakosti u društvu, moglo bi se pretpostaviti da u pozadini negativnih komentara stoje ekonomski, a u manjoj mjeri ideološki razlozi. Ali istraživanja ne potvrđuju da primjerice uvođenje multikulturalističkih politika utječe na slabljenje socijalne države. No ono što neka istraživanja pokazuju jest da multikulturalističke politike u zemljama s jakom socijalnom državom polučuju među migrantima slabe integracijske učinke. Osuda multikulturalističkih politika imala je i ima široke reperkusije na različite sfere društva te je između ostaloga i novi vjetar u leđa ekstremnijim političkim strankama koje se zalažu za restriktivnu useljeničku politiku i ograničen pristup državljanskim pravima.

Liberalna država, s druge strane, multikulturalističke politike smatra prijetnjom za svoja liberalna načela od kojih ne želi odstupiti niti ih prihvatiti pod geslom multikulturne tolerancije (Joppke, 2004). U prvom poglavlju rada daje se pregled triju multikulturnih teorija - liberalnog multikultu- 
ralizma, egalitarnog multikulturalizma i dijaloškog multikulturalizma, i njihova kritika. U drugom poglavlju raspravlja se o govorima političkih lidera triju europskih država - Francuske, Velike Britanije i Njemačke, u kojima se multikulturalističke politike osuđuje za integracijske neuspjehe te se nastoji odgovoriti što leži u pozadini negativnih komentara političara. Potom se, u trećem poglavlju daje pregled istraživanja o utjecaju multikulturalističkih politika na socijalnu državu te se iznose rezultati komparativne studije Ruuda Koopmansa (2010) o integracijskim učincima multikulturalističkih politika u osam europskih zemalja. U zadnjem poglavlju iznose se zaključna razmatranja o napuštanju jednodimenzionalnoga teorijskog pristupa i uvođenju integrativne multikulturne teorije, o pokušajima da se multikulturalističke politike integracije migranata zamijeni asimilacijskima te $\mathrm{u}$ kontekstu rasprave o multikulturalizmu o suodnosu politika ekonomske redistribucije i priznavanja različitosti.

\section{TRI LICA MULTIKULTURALIZMA}

Multikulturalizam je iznikao iz liberalne misli i smatra se liberalnodemokratskim fenomenom (Kymlicka, 2007: 97), pa se o njemu najčešće teoretizira iz liberalne perspektive. Moguće ga je klasificirati na razne načine, pri čemu su dvočlane tipologije najčešće, a nisu rijetke ni tročlane i višečlane (Mesić, 2006: 125). ${ }^{1} \mathrm{U}$ ovom će se poglavlju osvrnuti na tri inačice multikulturalizma: liberalni multikulturalizam, egalitarni multikulturalizam i dijaloški multikulturalizam.

Razvoj i širenje liberalnog multikulturalizma na Zapadu mogu se promatrati kroz procese liberalizacije i demokratizacije društva i socijalnih politika započete šezdesetih godina 20. stoljeća kao što su liberalizacija tzv. reproduktivnih prava (pravo na pobačaj i kontracepciju), liberalizacija prava na razvod, ukidanje smrtne kazne, zabranjivanje rodne i vjerske diskri-

\footnotetext{
G. Matteo (2001) razlikuje dvije koncepcije multikulturalizma utemeljene na distinkciji antropoloških i normativnih interpretacija kulture. S jedne su strane liberali i komunitarijanci, koji zastupaju institucionalni pogled na kulturu, dok su s druge postmoderni teoretičari, koji ističu njezino relacijsko shvaćanje. Najvažnija je distinkcija između dva koncepta u različitom razumijevanju kulture (Matteo prema Mesić, 2006: 126). M. Walzer (1994) kroz dva tipa liberalizma nastoji objasniti pristajanje uz određeni oblik multikulturalizma. Dok su u jednoj inačici liberalizma najviše naglašena individualna prava i neutralnost države, druga inačica zalaže se za državu koja forsira održavanje i napredak određene/određenih nacije/a, kulture/a ili religije/a sve dok su zaštićena osnovna prava državljana (Walzer, 1994: 100-101). Pokušaji da se multikulturalizam klasificira u tri tipa prisutni su kod Sasje Tempelman (1999), koja razlikuje primordijalni, civilni i univerzalni tip. Ta podjela proizlazi iz razlika u pristupu održavanju kulturnih zajednica, međukulturnoj interakciji te ograničenjima pluralizma.
} 
minacije te dekriminalizacija homoseksualnosti (Kymlicka, 2007: 97). Osim što se uvođenjem tih prava društvo liberaliziralo, ono se i sekulariziralo te omogućilo daljnje kreiranje prava pojedinaca i skupina koje ne čine glavni tok društva.

Najpoznatiji teoretičar liberalnog multikulturalizma Will Kymlicka uvjeren je da je upravo liberalni multikulturalizam najbolji način izgradnje pravednog i inkluzivnog društva. On poput drugih liberalnih teoretičara (Taylor, 1994; Raz, 1994) smatra da se u liberalizmu dugo ignorirala činjenica o važnosti kulture u izgradnji pravednog društva. Stoga, da bi se osjećali autonomnim bićima, ljudi moraju imati pristup socijetalnoj kulturi izbora koja članovima svoje skupine osigurava smislene načine života u različitim sferama društva. Pripadanje nekoj kulturi i kulturni kontekst postaju važan element $\mathrm{u}$ ostvarenju autonomije pojedinca. Grupno diferencirane mjere koje osiguravaju i promoviraju pristup socijetalnoj kulturi izbora, prema Kymlickinu shvaćanju, posve su legitimne u okviru liberalne teorije pravednosti (Kymlicka, 2003).

Stavši u obranu manjinskih prava, Kymlicka smatra da tzv. pristup slijep na različitost koji zagovara tradicionalni liberalizam treba biti komplementaran s priznavanjem manjinskih prava. Ovdje je riječ o posebnim pravnim ili ustavnim mjerama koje su iznad državljanskih prava u cilju obrane kulture, religije ili identiteta manjinskih skupina. No Kymlicki je osiguranje mogućnosti individualnog izbora važnije od same obrane tj. zaštite kultura. $S$ obzirom na to da je liberal, on pojedinca stavlja ispred zajednice i stoga svoje shvaćanje multikulturalizma naziva liberalnim. Priznavanje prava kulturno specifičnih skupina treba omogućiti, ali ne prema njihovim uvjetima, nego samo prema tzv. univerzalističkim načelima, a to su individualna sloboda i društvena pravednost. Iako je Kymlicka takvim konceptom želio postići univerzalnost, skliznuo je u isključivost jer se uvođenjem individualne slobode kao univerzalne vrijednosti ustvari promovira kulturno vrlo specifičan pogled na život. Iako neke liberalne vrijednosti imaju univerzalni karakter, to ne znači da u kontaktu liberalnih i nelibelarnih kultura sve liberalne vrijednosti treba dogmatski slijediti pridajući im univerzalnu važnost (Parekh, 2008).

Pitanje je li multikulturalizam iznad liberalnih vrijednosti otvara nove rasprave kad je posrijedi Kymlickino tumačenje grupno-diferenciranih prava. Termini kao što su "grupno-diferencirano građanstvo«, "polietnička prava« $\mathrm{i}$ »prava iznad i pored zajedničkih državljanskih prava« egalitarne liberale užasavaju jer ostavljaju utisak da je multikulturalizam iznad liberalizma te da ta prava nadilaze zajednička državljanska prava. 
Kymlicka je također nejasan kad je posrijedi svrha polietničkih manjinskih prava. $S$ jedne strane on podupire uvođenje posebnih prava etničkim manjinama ako je kulturna pripadnost uzrokovala nepovoljan društveni položaj, a s druge ne prihvaća mogućnost privremenosti manjinskih prava jer kulturne razlike koje ta prava štite nisu nešto što treba ukinuti. Kymlicka ne objašnjava trebaju li manjinska prava zaštititi kulturni identitet kao takav ili ona služe dokidanju nejednakosti i postizanju pravedno utemeljenih ciljeva poput jednakih mogućnosti i jednakih sloboda (Loobuyck, 2005: 115).

Osim spomenutih kritika i osporavanja najžešću kritiku liberalnog multikulturalizma kako ga je Kymlicka uobličio iznio je Brian Barry, najpoznatiji predstavnik egalitarnog liberalizma. On naime želi dokazati da je multikulturalizam kao politički program politike različitosti u većini slučajeva loš i da je antiliberalan. Barry smatra da bi se politizaciji grupnih identiteta i donošenju posebnih politika za skupine trebalo oduprijeti ponajprije stoga jer se njima opstruira, a ne potiče uključivanje manjinskih kultura $u$ društvo, što bi im trebala biti svrha (Barry, 2006: 28). Liberalna doktrina s postojećim liberalnim pravima i mjerama ne treba posezati ni za kakvim posebnim manjinskim pravima, smatra Barry, jer u liberalnom društvu za sve treba vrijediti isti zakon, odnosno zakoni sve ljude moraju tretirati na jednaki način bez obzira na njihovu etničku ili vjersku pripadnost. Kritičari liberalnog multikulturalizma ističu kako u liberalizmu nema mjesta za prava koja se isključivo temelje na članstvu u nekoj kulturnoj skupini i čiji je cilj obnavljanje i zaštita kulturnog identiteta. Dok zagovornici multikulturalizma smatraju da u javnoj sferi društva treba poštovati načelo pluralnosti kad god je to moguće, a načelo neutralnosti kada je to neophodno, pripadnici liberalnoga glavnog toka zalažu se za što veću neutralnost javne sfere. ${ }^{2}$

Egalitarni liberali nadalje smatraju da nepovoljan položaj u kojemu se osoba našla, a da za to nije odgovorna, bez pogovora nalaže zahtjev za kompenzacijom. U skladu s tim uvođenje posebnih mjera u obliku pružanja pomoći članovima prikraćenih skupina ne kosi se s načelima egalitarnog liberalizma (Dworkin, 1981; Barry, 2001). Kada su posrijedi grupno diferencirana prava tj. mjere, Barry ističe da one uvijek trebaju biti privremene. To je zato što je posebni tretman prema nekoj skupini opravdan samo dok postoje nepravedno utemeljene nejednakosti. Posebni tretman u smislu grupno diferenciranih prava trebao bi služiti poboljšanju integracije određenih skupina u društvo i eliminiranju nepravedne nejednakosti (Barry, 2006: 14). No grupno diferencirane mjere potrebne da bi nadoknadile nejednakost

Francuska ideja laïcité $\mathrm{i}$ »radikalnog sekularizma« dobar je primjer takve nemultikulturne interpretacije liberalizma (Loobuyck, 2005: 112). 
mogućnosti ili nedostatak resursa, prema načelima egalitarnog liberalizma, trebaju biti u skladu s dobro definiranim uvjetima.

Barry priznaje da ima slučajeva u kojima grupno utemeljena prava pomažu ostvariti egalitarne liberalne ciljeve skupinama koje pate od sistemskog prikraćivanja i žive u nepovoljnom položaju te se njima nastoje smanjiti nejednakosti koje se odnose na manjkove resursa i mogućnosti. No on navodi da multikulturni argument za kulturno utemeljena prava ne ovisi o takvoj vrsti nejednakosti jer se skupine definira po njihovim distinktivnim kulturnim obilježjima, a posebna prava trebala bi biti trajna ili barem trajati dok skupina zadržava svoju kulturnu posebnost. Ako neka skupina više ne treba posebna prava, zagovornici multikulturalizma to ne shvaćaju kao nešto pozitivno, nego smatraju da potpora kulturi te skupine nije bila dovoljna da je održi i njezine članove zaštiti od asimilacije u kulturu neke veće ili moćnije skupine (Barry, 2006: 14-15).

Budući da multikulturalističke politike i mjere nisu oblikovane da pojačavaju razlike, nego da promoviraju uključivanje i omogućuju integraciju članova pojedinih skupina u društvo, egalitarni liberali smatraju da ne postoji nijedan validan razlog da se skupine posebno tretiraju ako među njima (više) ne postoji nejednakost. Zaštita, priznavanje i ovjekovječenje kultura i grupnih identiteta zbog njih samih nije dovoljan razlog za uvođenje multikulturalističkih politika. One su neophodne samo ako stvarno služe ispravljanju nepovoljne situacije koja je za pojedine skupine nepravedna.

Jedan od najistaknutijih političkih teoretičara multikulturalizma Bhikhu Parekh iznosi teoriju multikulturalizma koja se najčešće naziva dijaloškom. U njoj središnje mjesto zauzima dijalog među kulturama koji treba biti institucionaliziran, što je potanko razložio u svojoj knjizi Rethinking Multiculturalism: Cultural Diversity and Political Theory (2000).

Parekh napominje da ne treba težiti konstruiranju liberalne teorije multikulturalizma kao što su to primjerice učinili Kymlicka i još neki drugi teoretičari, zbog dva razloga. Prvi je zato što bi takva teorija još više produbila i proširila teorijske postavke liberalizma i uvjerila liberale da ih prihvate, a drugi što takva teorija ne može pružiti intelektualno koherentan i moralno prihvatljiv teorijski temelj multikulturnog društva. $S$ obzirom na to da sebe ne možemo transcendirati i smjestiti u prostor koji nadilazi liberalne i neliberalne kulture, Parekh temelje te filozofske apstrakcije vidi u institucionalnom dijalogu različitih kultura (Parekh, 2000: 14). On također predlaže da se liberalno shvaćanje relativizira uzdizanjem na jednu višu filozofsku razinu u kojoj nijedna kultura nije posebnija od druge. Parekhu je naime iznimno važno pitanje kako se liberalizam treba odnositi prema neliberal- 
nim skupinama, pri čemu naglašava da treba uzeti u obzir i manje liberalne poglede na život. Ističe da se multikulturalizam ustvari ne bavi manjinama jer bi to impliciralo da se većinska kultura nekritički prihvaća te prosuđuje zahtjeve i definira prava manjina, nego se tiče stvaranja odgovarajućih uvjeta potrebnih da bi različite kulturne zajednice stupile u odnos (Parekh, 2000: 13). Iz toga proizlazi da se multikulturalizam ne svodi na prava manjinskih kultura, nego na vrijednost kulturne različitosti koja je utkana u svako suvremeno društvo u kojem »njegovi članovi žive unutar različitih sustava značenja i smisla, koji se međusobno preklapaju« (Parekh, 2008: 71).

Iako kulturna različitost u modernom društvu ima više izvora, važan izvor različitosti Parekh vidi u useljavanju (2008: 71). Pritom napominje kako je važno izbjeći četiri česte pogreške vezane uz raspravu o useljavanju. Prvo, potrebno je ukloniti razmišljanje kako su društva prije useljavanja bila homogena. Useljavanje je tek jedan izvor kulturne različitosti te ako ono prestane, društva će i dalje bilo kulturno heterogena. Druga pogreška tiče se krive percepcije o useljenicima kao homogenoj, najčešće nebjelačkoj skupini. To je posve pogrešno, smatra Parekh, jer useljenici čine različite vjerske, etničke, rasne i druge skupine. Osim toga razlikuju se i s obzirom na svoja očekivanja, socijalni kapital, kulturne resurse i odnos prema zemlji useljavanja. Treće, iako se načinom života useljenici često razlikuju od većinskog stanovništva u zemlji domaćina, u moralnom smislu ta razlika nije toliko istaknuta. Naime različitost koju useljenici donose, ako izuzmemo njihov izgled i govor, nisu ništa veće od onih koje već postoje u društvima koja ih primaju. Često useljenici imaju više sličnosti s većinom domicilnog stanovništva koje ima konzervativne stavove nego što je svi pripadnici domicilnog društva imaju međusobno. Četvrta pogreška odnosi se na obrasce suvremenog useljavanja, koji se u bitnome razlikuju od tradicionalnih obrazaca. Dok su useljenici na početku 20. stoljeća i između dva svjetska rata dolazili kao izbjeglice zajedno s obiteljima bježeći od progona i bez većih se poteškoća asimilirali, među današnjim useljenicima, osim izbjeglica, puno je i radnih migranata koji dolaze zbog potreba tržišta rada zemalja useljavanja. Dok su se ovi prvi brzo asimilirali i održavali labave veze s matičnom zemljom ponajprije zbog slabo razvijenih sredstava komunikacije i transporta, suvremeni useljenici često održavaju veze sa svojim domovinama i zbog razvijenosti liberalnih politika mogu lakše, ako to žele, očuvati vlastiti identitet (Parekh, 2008: 72-73).

U shvaćanju multikulturalizma koje nudi Tariq Modood (2007) uočava se još jedan korak naprijed u odnosu na dijalošku formu multikulturalizma 
Bhikhua Parekha. Nadahnut idejama Parekha i Charlesa Taylora, ${ }^{3}$ Modoodov multikulturalizam usmjeren je ponajprije na ulogu religijskih manjinskih skupina u javnoj sferi, pri čemu se najviše bavi pitanjima tolerancije i naglašene sekularizacije $u$ modernim liberalnim društvima. Multikulturalizam bi, smatra on, trebao nuditi više od tolerancije i pružati aktivnu podršku kulturnim različitostima. Trebao bi obeshrabrivati i suzbijati neprijateljstvo prema određenim skupinama i pojedincima te preoblikovati javnu sferu kako bi došlo do uključivanja marginaliziranih identiteta (Modood, 2007: 64). Modood se zalaže za aktivnu politiku priznavanja koja uključuje dvosmjerni dijalog i proces učenja u kojemu su odnosi moći i sudjelovanja obiju strana izjednačeni (Modood, 2007: 65). Priznavanje različitosti, prema Modoodu, ne zahtijeva odobravanje ili neodobravanje različitosti, nego je to način stvaranja pozitivnog dijaloga koji utječe na veću uključenost svih skupina u proces izgradnje nacije. Želi se postići da taj proces odražava različitosti koje postoje u nekoj državi, pri čemu se ne traži prihvaćanje praksi i vjerovanja koje su protivne nečijim moralnim načelima. Ovdje je politika priznavanja shvaćena kao omogućivanje pravednijih uvjeta integracije manjinskim skupinama. Pružajući tim skupinama mogućnost da sudjeluju u javnim raspravama te da u javnosti budu prihvaćeni kao nositelji posebnih kulturnih identiteta, država će moći bolje odgovoriti na njihove zahtjeve. Takva vizija multikulturalizma kroz uključivanje kulturnih, etničkih i religijskih skupina $u$ javnu sferu briše striktnu podjelu na javno i privatno (Modood, 2007: 146). Očito je da u takvu shvaćanju multikulturalizma manjinske skupine imaju puno veći ulog u oblikovanju državnih institucija i u javnoj sferi nego što ga imaju u liberalnome multikulturalizmu. Liberalni multikulturalizam ustvari želi manjinske skupine i njihove kulture zaštititi od negativnog utjecaja koji proces izgradnje nacije ima po njih.

\footnotetext{
Charles Taylor uobličio je svoj teorijski model multikulturalizma koji je nazvao politikom priznavanja u svojoj čuvenoj raspravi Politika priznavanja (1994). U njemu je iz historijskofilozofske perspektive iznio razvoj toga koncepta i ključna pitanja koja taj koncept iznosi pred liberalnu teoriju društva. Svojim konceptom politike priznavanja Taylor upozorava na strukturnu povezanost porasta individualizacije i multikulturnih zahtjeva. Naglašava kako je identitet univerzalna kategorija, jer svatko ga ima, no ujedno i specifična te stoga treba priznati ono što je specifično za svakoga. Deprivilegiranim skupinama u društvu trebalo bi nadoknaditi povijesnu nepravdu uvođenjem posebnih prava i zajamčiti jednakost s privilegiranom većinom. Kritičari multikulturalizma optužili su ga za dokidanje slobode pojedincu i njegovo utapanje u kolektiv. No važnost politike priznavanja u novije je vrijeme općeprihvaćena (Mesić, 2006: 76-78).
} 


\section{NAPADI NA MULTIKULTURALIZAM I NJIHOVA POZADINA}

Izazovi vezani uz integraciju novijih migracijskih i izbjegličkih tokova u Europi puno su kompleksniji od onih u prošlim razdobljima. Društva koja primaju veliki broj migranata, kako radnih tako i onih koji traže zaštitu, ne uspijevaju uvijek naći najpogodniji okvir za njihovo uključivanje u društvo ili ih maknuti iz nepovoljnog i marginaliziranog položaja. Rasprava o učincima multikulturalističkih politika koja je najviše odjeknula u europskome javnom prostoru, počela je u listopadu 2010. kada je njemačka kancelarka Angela Merkel na skupu Mladeži CDU-a (Jungen Union) u Potsdamu izjavila kako multikulturalizam u Njemačkoj nije uspio, a nastavila se nekoliko mjeseci poslije iznošenjem sličnih stavova o multikulturalizmu britanskog premijera Davida Camerona te francuskog predsjednika Nicolasa Sarkozya.

U svom govoru u Potsdamu Angela Merkel izjavila je da je multikulti u Njemačkoj podbacio te da on ne osigurava uvjete za život u kojima različite kulturne i etničke skupine žive sretno jedne kraj drugih. ${ }^{4}$ Nedugo nakon njemačke kancelarke, početkom veljače 2011., na multikulturalizam se okomio i David Cameron izjavivši da su multikulturalističke politike pridonijele stvaranju odvojenih svjetova u kojima imigrantske zajednice žive odvojeno od glavnog toka društva. One su ujedno zakazale u stvaranju društva prema kojemu svi (a posebno mladi muslimani) osjećaju pripadnost. ${ }^{5}$

Samo nekoliko dana nakon Camerona i Nicolas Sarkozy izjavljuje da je multikulturalizam neuspješan koncept, a razloge tome između ostaloga vidi u državama koje su previše usmjerene na identitet ljudi koji dolaze, a premalo na identitet pripadnika društva koje ih prima. U svom govoru istaknuo je da takav model integracije jača ekstremizam među imigrantima. Iako je važno uvažavati kulturne različitosti, on smatra da Francuska treba biti jaka nacionalna zajednica, a ne mjesto gdje različite kulturne/etničke zajednice naprosto koegzistiraju. ${ }^{6}$

Ne treba smetnuti s uma da nijedna od tri navedene zemlje (Njemačka, Francuska i Velika Britanija) na nacionalnoj razini nije usvojila multikulturalizam kao službenu politiku integracije migranata. Velika Britanija, doduše, primjer je »mekše« verzije multikulturalizma, ${ }^{7}$ dok su Francuska i Nje-

4 http://www.spiegel.de/politik/deutschland/integration-merkel-erklaert-multikulti-fuergescheitert-a-723532.html.

5 https://www.theguardian.com/politics/2011/feb/05/david-cameron-muslim-extremism.

6 http://www.liberation.fr/france/2011/02/11/sarkozy-estime-que-le-multiculturalisme-estun-echec_714298.

7 Britanski model multikulturalističke politike prepoznaje se, između ostaloga, po tome što primjerice ne postoje odvojeni školski programi (kurikuli) za određene etničke i vjerske 
mačka na nacionalnim razinama ostale dosljedne politikama diferencijalne isključenosti i asimilacije s manjim ili većim odstupanjima. ${ }^{8}$ No kako se sve veći broj gradova u spomenutim zemljama u posljednja dva desetljeća suočava sa snažnim porastom imigranata, primjetan je razvoj multikulturalističkih politika na lokalnim razinama. Lokalne sredine, posebno gradovi, ali i pokrajinske vlasti, snažno su se angažirale oko donošenje adekvatnih mjera i politika u cilju uključivanja novopridošlih skupina u društvo i održanja društvene kohezije te su u tome poprilično uspješne (Escafré-Dublet, 2014; Bendel, 2014). Lokalne vlasti često su prinuđene same donositi integracijske mjere i prilagoditi ih potrebama imigranata, nerijetko ispravljajući ili ublažavajući neuspjehe državnih politika u rješavanju izazova na lokalnim razinama. Francuska i Njemačka dobar su primjer kako su gradovi asimilacijske i politike diferencijalne isključivosti zamijenili multikulturalističkim politikama, dok to nije učinjeno i na državnim (nacionalnim) razinama (Alexander, 2003: 411-427).

No unatoč postignućima multikulturalističkih politika na lokalnim, pokrajinskim i u nešto manjoj mjeri državnim razinama, veliki broj migranata i dalje je deprivilegiran i živi u nepovoljnim socijalnim uvjetima. To se ne odnosi samo na spomenute tri zemlje nego još i više na zemlje koje imaju puno razvijenije (Belgija, Nizozemska i Norveška) ili čak proklamirane (Švedska) multikulturalističke politike. Rezultati nekih istraživanja (Murdie i Borgegard, 1998; Phillips, 1999; Koopmans, 2010) pokazuju da zemlje $\mathrm{s}$ razvijenim multikulturalističkim politikama nisu uspjele u uključivanju migranata u glavni tok društva, posebno ne u socioekonomskom pogledu. Veliki broj migranata i dalje je ovisan o socijalnoj pomoći, ima nisku stopu zaposlenosti, a visoku nezaposlenosti, živi u lošijim stambenim uvjetima od domicilnog stanovništva, njihova djeca imaju nižu razinu obrazovanja od prosjeka i ranije napuštaju obrazovni sustav, prostorno su segregirani i kvaliteta života im je lošija. Na to upućuju i OECD/EU indikatori integracije migranata (OECD/EU, 2015).

Na kraju se postavlja pitanje o pozadini napada na multikulturalizam državnika čije države nisu usvojile multikulturalizam kao službenu poli-

skupine, već se samo daju preporuke obrazovnim ustanovama kako postupati s rasnom, etničkom i religijskom različitošću, primjenjuju se izuzeća kada su posrijedi Sikhi i nošenje turbana na radnome mjestu i kod vožnje motocikala, dopuštena su izuzeća u korist konzumacije halal i košer hrane te se osim kršćanskoj prava daju i drugim religijama, tj. vjerskim ustanovama da osnivaju vjerske škole (Heath i Demireva, 2014: 165-167).

8 Castles (1995) klasificirao je integracijske politike u četiri kategorije s obzirom na odnos i odgovor države prema strancima tj. imigrantima. Tako on razlikuje model potpune isključenosti, diferencijalne isključenosti, asimilacijski i pluralistički model. 
tiku kojom se reguliraju prava manjinskim i skupinama migrantskog porijekla. Smisao negativnih komentara triju političara trebalo bi shvatiti kao nepristajanje na uvođenje multikulturalističkih politika, i to zbog ekonomskih, a u manjoj mjeri ideoloških razloga. Kad je riječ o Njemačkoj, Kraus i Schönwälder (2006) navode da je otpor političara prema multikulturalizmu ukorijenjen u povezanosti i suodnosu njemačke socijalne države i tržišta rada. Naime prisutan je strah da bi multikulturalističke politike mogle ugroziti funkcioniranje socijalne države, a posljedično i političke strategije utemeljene na načinima njezina funkcioniranja. Iako se u novije vrijeme Njemačka otvara ideji multikulturalizma, u tome je vrlo oprezna. To potvrđuju i snažne rasprave unutar njemačke ljevice, posebice unutar stranke socijalnih demokrata (SPD), o tome treba li prihvatiti multikulturalističke politike i u kojoj bi mjeri zaokret prema takvim politikama utjecao na izborne rezultate i ostvarenje izbornih obećanja vezanih uz raspodjelu sredstava za socijalne namjene.

U slučaju Velike Britanije, slično kao i u Njemačkoj, negativne ocjene političarâ upućene na račun multikulturalizma tiču se ekonomskih, a manje ideoloških razloga. Naime te se politike povezuju sa sredstvima koja socijalna država izdvaja za marginalizirane članove društva kao što su primjerice neke migrantske skupine, pa bi njihovo dokidanje moglo smanjiti migracijski pritisak. Osim toga multikulturalističke politike kao što su politike priznavanja, politike različitosti i politike identiteta smatra se nedovoljno snažnima za izgradnju povjerenja i solidarnosti među pripadnicima britanskog društva i ujedno odgovornima za slabljenje nacionalnih politika. Premda u Velikoj Britaniji nije došlo do značajnijeg uzmaka od multikulturalističkih politika, povećala su se izdvajanja za financiranje tečajeva engleskog jezika te su uspostavljene ceremonijalne svečanosti s izricanjem prisege prilikom dobivanja državljanstva u cilju jačanja osjećaja nacionalnog pripadanja (Banting i Kymlicka, 2004: 21-22).

Antimultikulturalistička vladina retorika u Francuskoj bila je, čini se, samo povod za isticanje važnosti jačanja nacionalnog identiteta kao važnog preduvjeta uspješne integracije imigranata. Dosljedan republikanskim načelima koja su slijepa na različitosti, Sarkozy je svojim govorom potvrdio da bilo kakvo priznavanje posebnih prava imigrantima, uvođenje mjera pozitivne diskriminacije i sl. u francuskom društvu nije dobro došlo, barem ne na državnoj razini. Unatoč tomu što je isticanje nacionalnog identiteta trebalo poslužiti za jačanje ideje kohezije i inkluzije pripadnika različitih etničkih skupina, Simon (2012) smatra da rasprava o nacionalnom identitetu više razjedinjuje nego što povezuje pripadnike društva jer se njome još 
više naglašava razlika između onih koji osjećaju pripadnost nacionalnome francuskom identitetu i onih koji to (još) ne osjećaju.

\section{MULTIKULTURALISTIČKE POLITIKE, SOCIJALNA DRŽAVA I INTEGRACIJSKI UČINCI}

Mnoštvo je istraživanja i teorijskih promišljanja (Banting i Kymlicka, 2004; Banting i sur., 2006; Entzinger, 2006; Evans, 2006; Kraus i Schönwälder, 2006; Miller, 2008) u kojima se propituju odnosi i povezanost etničke različitosti, multikulturalizma i socijalne države. No puno manje ima istraživanja posvećenih povezanosti multikulturalističkih politika i integracije migranata u zemljama s izdašnom socijalnom državom (Koopmans, 2010).

Rezultati studija (Banting i Kymlicka, 2004; Banting i sur., 2006; Evans, 2006; Entzinger, 2006; Miller, 2008) koje se bave utjecajem multikulturalističkih politika na socijalnu državu upućuju da multikulturalističke politike same po sebi nisu odgovorne za slabljenje socijalne države, tj. smanjenje raspodjele sredstava za socijalne namjene. U studiji o dvadeset tri tipa multikulturalističkih politika Banting i sur. (2006) testiraju jesu li zemlje s razvijenijim multikulturalističkim politikama suočene $s$ osiromašenjem i erozijom socijalne države u odnosu na zemlje u kojima su te politike slabije razvijene. Pokazalo se da usvajanje multikulturalističkih politika ne utječe na osiromašenje ili slabljenje socijalne države te čak da veličina imigrantskih skupina, nacionalnih manjina i domorodačkih naroda u zapadnim zemljama ne utječe na socijalnu državu i njezino funkcioniranje iako se čini da nagli porast imigrantske populacije utječe na raspodjelu socijalnih sredstava. Istražujući odnos multikulturalističkih politika i socijalne države u Britaniji, Evans (2006) zaključuje da u britanskom društvu ne postoji zazor od etničkih različitosti i multikulturalističkih politika te da u javnosti uglavnom prevladavaju tolerantni stavovi prema manjinama. Razloge slabljenja socijalne države ne nalazi u imigraciji ili multikulturalističkim politikama, nego u krizi gospodarskog sektora. U Njemačkoj, suprotno od Velike Britanije, iako ne postoje istraživanja o slabljenju socijalne države zbog uvođenja multikulturalističkih politika, postoji strah da bi se to moglo dogoditi te stoga i otpor prema uvođenju takvih politika (Kraus i Schönwälder, 2006). Vezano uz raspravu o faktorima koji utječu na izdašnost socijalne države, Miller (2008: 378) postavlja pitanje je li posjedovanje državljanstva dovoljno jak kohezivni faktor za uspješno funkcioniranje socijalne države u razvijenim multikulturnim demokracijama čiji opstanak i uspješnost ovise o relativno visokoj razini međusobnog povjerenja i suradnje svih pripadnika 
društva. Da bi suvremene demokratske države imale jaku socijalnu drža$\mathrm{vu}$, njezini se pripadnici moraju osloniti na neku vrstu nacionalnih temelja, smatra Miller, a za njega je to »ustavni patriotizam«.

Zanimljive podatke o napuštanju proklamiranog multikulturalizma kao službene politike u Nizozemskoj iznio je Entzinger (2006) nastojeći objasniti je li napuštanju multikulturalističke politike uzrok slabljenje socijalne države do kojeg je došlo zbog izdašnog financiranja manjina i migrantskih skupina. Zaključuje da do svojevrsnog uzmaka od multikulturalističkih politika nije došlo zbog slabljenja socijalne države, nego zato što te politike nisu uspjele većinu pripadnika manjina i imigrantskih skupina uspješno integrirati u glavni tok nizozemskog društva, zbog čega su te skupine ostale marginalizirane.

I Ruud Koopmans (2010) iznosi sličan argument o napuštanju multikulturalističkih politika u Nizozemskoj, no svoju analizu proširuje uspoređujući nizozemsku integracijsku politiku s politikama sedam europskih imigracijskih zemalja. Koopmans želi dokazati kako olakšan pristup socijalnoj državi u kombinaciji s pogodnostima koje se daju na temelju kulturne različitosti ima negativan učinak na socioekonomsku integraciju migranata. Da bi to potvrdio, navodi primjer Nizozemske, u kojoj imigranti kad je posrijedi socioekonomska integracija stoje najlošije unatoč tome što su "priznati« i uživaju mnoga prava koja iz toga priznanja proizlaze. Također navodi da i Švedska i Belgija, koje najviše sliče nizozemskome modelu multikulturalističke politike s izdašnom socijalnom državom, imaju slične nepovoljne integracijske učinke. Iznosi tezu da u državama s jakom socijalnom državom multikulturalizam nije nužno uopće koristan za imigrante jer može dovesti do ovisnosti o sustavu socijalne pomoći te posljedično do sve veće društvene i ekonomske marginalizacije (Koopmans, 2010: 2).

Uspoređujući strukturu i načine funkcioniranja socijalnih država $u$ osam analiziranih zemalja, Koopmans spominje tri tipa socijalne države. Socijalno-demokratski tip prisutan je u Švedskoj, liberalni u Velikoj Britaniji, a u Francuskoj, Njemačkoj i Švicarskoj konzervationi. U Austriji, Belgiji i Nizozemskoj prisutna je kombinacija konzervationog i socijalno-demokratskog tipa. Koopmans naime smatra da su integracijske politike i mehanizam socijalne države snažno povezani. O vrsti integracijske politike ovise pristup i ostvarivanje jednakih prava imigranata te korištenje socijalnim naknadama. U tom smislu nastoji dokazati da je uključenost imigranata u tržište rada niža u zemljama s izdašnijom socijalnom državom socijalno-demokratskog tipa kao što je primjerice Švedska, dok je viša u zemljama s liberalnom socijalnom državom poput Velike Britanije. No tumačenje socioekonomske 
integracije imigranata pomoću načina funkcioniranja socijalne države ne objašnjava zašto je u Austriji, Njemačkoj i Švicarskoj uključenost imigranata u tržište rada čak i veća nego u Velikoj Britaniji, dok je u Nizozemskoj i Belgiji-Flandriji niža nego u Švedskoj. Da bi to objasnio, Koopmans iznosi sljedeći argument. Objašnjava da je uključenost imigranata u tržište rada obrnuto proporcionalna s lakoćom ostvarenja jednakih prava i izostankom pritiska za kulturnom asimilacijom. Na kraju zaključuje da su u zemljama koje ujedno imaju ograničen pristup socijalnoj državi i restriktivne ili asimilacijske integracijske politike imigranti najviše uključeni u tržište rada. Suprotno tomu, u državama s izdašnom socijalnom državom i olakšanim dobivanjem državljanskih prava te ograničenim asimilacijskim pritiskom (Švedska, Nizozemska i Belgija-Flandrija) uključenost je imigranata u tržište rada najslabija. Osim socioekonomske uključenosti Koopmans analizira i uspoređuje osam zemalja s obzirom na stupanj stambene segregacije te prisutnost kriminaliteta među imigrantima. Zaključuje da je stambena segregiranost prisutnija u zemljama s multikulturalističkim integracijskim politikama kao što su Švedska, Belgija, Nizozemska i Velika Britanija, dok je puno manje prisutna u onima s asimilacijskim politikama. Pritom je visoka razina prostorne segregiranosti u kombinaciji s niskom uključenošću u tržište rada prisutna u Švedskoj i Belgiji, dok je u Velikoj Britaniji uz visoku prostornu segregiranost imigranata prisutna i njihova relativno visoka razina uključenosti u tržište rada. No to ne vrijedi za skupine imigranata iz Pakistana i Bangladeša, koji osim što su prostorno najsegregiraniji u odnosu na druge imigrantske skupine, ujedno su i najmanje zastupljeni na tržištu rada (Modood prema Koopmans, 2010: 7-17).

Polazeći od pretpostavke da je vjerojatnost kriminalnog ponašanja snažno povezana s društveno-ekonomskim položajem pojedinca, Koopmans iznosi hipotezu prema kojoj imigranti čine većinu u zatvorima zemalja $\mathrm{s}$ niskom razinom sudjelovanja imigranata u tržištu rada. Na temelju uvida $\mathrm{u}$ zatvorske dokumentacije utvrđuje da je u Nizozemskoj broj imigranata u zatvorima veći šest do osam puta od broja ostatka populacije. U Velikoj Britaniji vjerojatnost da će imigranti i pripadnici etničkih manjina završiti u zatvoru tek je dva ili tri puta veća nego kod neimigrantske ili većinske populacije. U Švedskoj i Belgiji situacija je slična kao i u Nizozemskoj, dok je u Njemačkoj i Austriji te u manjoj mjeri u Švicarskoj zastupljenost imigranata u zatvorima niža nego u ostalim zemljama. Francuska se po zastupljenosti imigranata u zatvorima nalazi negdje u sredini.

Na kraju rada Koopmans zaključuje da su različita shvaćanja o tome kako imigrante treba integrirati u društva primitka odnosno različite inte- 
gracijske politike utjecali na integracijske učinke imigranata. Pritom izdvaja primjer Nizozemske, čija integracijska politika utemeljena na multikulturnim načelima predstavlja svojevrsni eksperiment među europskim zemljama i poprilično otrežnjenje od pokušaja da se imigrante integrira multikulturalističkom politikom na državnoj razini. Suočena s niskom razinom uključenosti imigranata u tržište rada, snažnom segregiranošću imigrantskih zajednica i visokom razinom kriminaliteta među imigrantima u odnosu na ostale (europske imigracijske) zemlje, Nizozemska se s pravom upitala o svrsishodnosti multikulturalističkih politika, posebno uspoređujući svoje i integracijske učinke u zemljama koje takve politike nisu provodile ili nisu u tolikoj mjeri. Stoga je u provođenju multikulturnih mjera učinila zaokret uvođenjem obaveznih integracijskih tečajeva kako za novopridošle migrante tako i za one ovisne o socijalnoj pomoći. Potrebno je također napomenuti da su multikulturalističke politike možda uspješnije u nekim drugim područjima kao što je primjerice politička participacija imigranata nego u područjima socioekonomske participacije.

Na kraju bi ipak trebalo objasniti, smatra Koopmans, vjerodostojnost normativnih razloga za uvođenje multikulturalističkih politika, politika priznavanja i politika različitosti koje država financijski i institucionalno podupire, osim ako one nisu svrha same sebi (Koopmans, 2010: 18-21). To bi osim apologeta multikulturalizma, bez obzira na to bili oni politički filozofi, sociolozi ili politolozi, trebali učiniti i donositelji takvih politika.

\section{ZAKLJUČAK}

Imajući na umu činjenicu da ne postoji jedna integrativna teorija multikulturalizma koja pruža jasne odgovore na pitanja povezana s reguliranjem kulturnih, vjerskih i etničkih različitosti, $u$ radu su iznesena polazišta triju multikulturnih teorija kako bi se upozorilo na mnoštvo prijepora koji nastaju oko tih pitanja u modernim liberalnim društvima. Mnogo liberalnih i uopće progresivnih mislilaca smatra da smisleni multikulturalizam mora biti utemeljen na politici jednakosti, ekonomske redistribucije i društvenog restrukturiranja (Fraser,1997), što je sasvim sukladno cilju integracijskih politika, a to je da useljenici postanu jednakopravni građani te da budu povezani s ostatkom društva osjećajem zajedničke pripadnosti. No problem nastaje kod pokušaja ostvarenja toga cilja.

U raspravi o multikulturalizmu posebno je izražen rascjep kad je posrijedi ideja ekonomske redistribucije. S jedne strane naglasak je na ideji priznavanja različitosti bez poziva na ekonomsku redistribuciju, dok se s druge 
strane pitanje priznanja različitosti zanemaruje u korist ekonomske redistribucije. Postoje tako zagovaratelji multikulturalizma (a oni su većina) koje uopće ili jako malo zanimaju politike redistribucije kao što postoje i kritičari multikulturalističkih politika koji pak nemaju sluha za politike priznavanja identiteta. Punija koncepcija teorije multikulturalizma zahtijevala bi ukidanje ovakvih suprotnosti (usp. Hartmann i Gerteis, 2005), stoga smatramo da bi jednodimenzionalnu koncepciju trebalo zamijeniti integrativnijim konceptom koji uključuje i politiku različitosti i ekonomske redistribucije.

Multikulturalizam je osim u filozofsko-politološkim raspravama osporavan i od političara, tj. vladajućih struktura. Osuđuje ga se za razjedinjavanje društva u kojemu različite etničke i rasne skupine održavaju posebnost svojih kultura nauštrb društvene kohezije. Iako se toleriraju, društvene razlike iznutra se doživljavaju kao razdorne i kao takve prijetnja su društvenom jedinstvu. Govor predstavnika političkih elita osim kritike multikulturalizma sadržava prizivanje jednog novog asimilacionizma koji, čini se, predstavlja pragmatičan oblik uključivanja imigranata u društva, strukturno neophodan, iako ne baš moralno poželjan.

Troje državnika, predstavnika triju ekonomski najmoćnijih europskih zemalja, implicitno (i manje implicitno) ne podržava različitost, a to je ustvari mjesto na kojemu i liberalna kritika multikulturalizma ima naglasak. Red i stabilnost, prema njihovu mišljenju, uvijek je puno teže postići i održati u kontekstu različitosti. Svojevrsni povratak k asimilacijskim politikama odnosno teorijama prisutan je posebno u radovima istraživača iz SAD-a (Glazer, 1993; Portes i Zhou, 1993; Alba i Nee, 2003), koji još od početka devedesetih nastoje opravdati takve politike nalazeći u njima snažnu platformu koja umanjuje strukturne nejednakosti.

Dvojbeno je koliko bi ponovno uvođenje asimilacijskih politika u europskom kontekstu polučilo željene rezultate. Izgleda da uvođenje bilo kakvih krajnosti kada je riječ o uključivanju novopridošlih skupina u društva polučuje vrlo slabe integracijske učinke. Forsiranje kulturne asimilacije, uvođenje (strogih) integracijskih tečajeva i pridavanje važnosti isključivo socioekonomskoj dimenziji mogli bi biti podjednako pogubni kao i uvođenje multikulturalističkih politika koje forsiraju očuvanje kultura i identiteta, a zanemaruju važnost socioekonomske dimenzije.

Multikulturalističke politike u europskom kontekstu zakazale su, što najbolje pokazuje primjer Nizozemske (ali i Belgije i Švedske), i potrebno je učiti iz njihova iskustva. Imigrante nisu uspjele integrirati u društva primitka, što im je bio cilj, na što upućuju visoka stopa nezaposlenosti migranata, niža razina obrazovanja migrantske djece, prostorna segregiranost, visoka 
stopa kriminaliteta u odnosu na nemigrantsku populaciju itd. Osim toga ovdje se s pravom možemo zapitati o normativnoj ulozi očuvanja kultura po svaku cijenu, pa čak i kada svi pripadnici neke kulture ili etničke skupine nisu sigurni u kolikoj im je mjeri ta kultura važna za »vođenje dobrog života «. Kao što Barry (2006: 78) napominje, rođenje ili pripadnost određenoj etničkoj skupini čovjeka ne obvezuje na ulogu »čuvara« svoje »predačke kulture«. Ako netko želi slijediti tradicionalne načine života, to mu treba dopustiti, ali ne treba uvođenjem državnih politika prisiljavati na to one koji to ne žele. To pogotovo ne treba činiti u liberalnim društvima. Na kraju valja upozoriti da migranti koji se useljavaju u neko društvo nisu homogena skupina kako je Parekh (2008) naglasio. Oni se međusobno razlikuju po stupnju obrazovanja, stilovima života, etničkoj i/ili vjerskoj pripadnosti, socijalnom kapitalu koji sa sobom nose i mnogo čemu drugome. Prilikom donošenja svake politike čiji je cilj (i)migrante integrirati u društvo to bi trebalo imati na umu.

\section{LITERATURA}

Alba, R. D. i Nee, V. (2003). Remaking the American Mainstream: Assimilation and the New Immigration. Cambridge, MA: Harvard University Press, doi: https://doi. org/10.4159/9780674020115

Alexander, M. (2003). Local policies toward migrants as an expression of Host-Stranger relations: a proposed typology, Journal of Ethnic and Migration Studies, 29 (3): 411-430, doi: https://doi.org/10.1080/13691830305610

Banting, K. i Kymlicka, W. (2004). Do multiculturalism policies erode the welfare state?, Kingston: School of Policy Studies, Queen's University (Working Paper 33, revised version: December 2004), http://www.queensu.ca/sps/sites/webpublish.queensu. ca.spswww/files/files/Publications/workingpapers/33.pdf (23. 02. 2017.).

Banting, K., Johnston, R., Kymlicka, W. i Soroka, S. (2006). Do multiculturalism policies erode the welfare state? An empirical analysis, u: K. Banting i W. Kymlicka (ur.). Multiculturalism and the Welfare State: Recognition and Redistribution in Contemporary Democracies. Oxford: Oxford University Press, 49-91, doi: https://doi.org/10.1093/acp rof:oso/9780199289172.003.0002

Barry, B. (2001). Culture and Equality: An Egalitarian Critique of Multiculturalism. Cambridge: Polity Press.

Barry, B. (2006). Kultura i jednakost: egalitarna kritika multikulturalizma. Zagreb: Naklada Jesenski i Turk.

Bendel, P. (2014). Coordinating Immigrant Integration in Germany: Mainstreaming at the Federal and Local Level. Brussels: Migration Policy Institute Europe.

Castles, S. (1995). How nation-states respond to immigration and ethnic diversity?, Journal of Ethnic and Migration Studies, 21 (3): 293-308, doi: https://doi.org/10.1080/13 69183x.1995.9976493 
Dworkin, R. (1981). What is equality? Part II: Equality of resources, Philosophy and Public Affairs, 10 (4): 283-345.

Escafré-Dublet, A. (2014). Mainstreaming Immigrant Integration Policy in France: Education, Employment, and Social Cohesion Initiatives. Brussels: Migration Policy Institute Europe.

Entzinger, H. (2006). The parallel decline of multiculturalism and the welfare state in the Netherlands, u: K. Banting i W. Kymlicka (ur.). Multiculturalism and the Welfare State: Recognition and Redistribution in Contemporary Democracies. Oxford: Oxford University Press, 177-201, doi: https://doi.org/10.1093/acprof:oso/9780199289172.003.0006

Evans, G. (2006). Is multiculturalism eroding support for welfare provision? The British case, u: K. Banting i W. Kymlicka (ur.). Multiculturalism and the Welfare State: Recognition and Redistribution in Contemporary Democracies. Oxford: Oxford University Press, 152-176, doi: https://doi.org/10.1093/acprof:oso/9780199289172.003.0005

Geddes, A. (2003). The Politics of Migration and Immigration in Europe. London - Thousand Oaks - New Delhi: Sage.

Glazer, N. (1993). Is assimilation dead?, Annals of the American Academy of Political and Social Science, 530 (1): 122-136, doi: https://doi.org/10.1177/0002716293530001009

Fraser, M. (1997). From redistribution to recognition? Dilemmas of justice in a "postsocialist" age, u: C. Willett (ur.). Theorizing Multiculturalism: a Guide to the Current Debate. Malden, MA: Blackwell, 19-49.

Hartmann, D. i Gerteis, J. (2005). Dealing with diversity: mapping multiculturalism in sociological terms, Sociological Theory, 23 (2): 218-240, doi: https://doi.org/10.1111/ j.0735-2751.2005.00251.x

Heath, A. i Demireva, N. (2014). Has multiculturalism failed in Britain?, Ethnic and Racial Studies, 37 (1): 161-180, doi: https://doi.org/10.1080/01419870.2013.808754

Joppke, C. (2004). The retreat of multiculturalism in the liberal state: theory and policy, The British Journal of Sociology, 55 (2): 237-257, doi: https://doi.org/10.1111/j.14684446.2004.00017.x

Kraus, P. A. i Schönwälder, K. (2006). Multiculturalism in Germany: rhetoric, scattered experiments and future chances, u: K. Banting i W. Kymlicka (ur.). Multiculturalism and the Welfare State: Recognition and Redistribution in Contemporary Democracies, Oxford: Oxford University Press, 202-221, doi: https://doi.org/10.1093/acprof:o so/9780199289172.003.0007

Loobuyck, P. (2005). Liberal multiculturalism: a defence of liberal multicultural measures without minority rights, Ethnicities, 5 (1): 108-135, doi: https://doi. org/10.1177/1468796805051679

Koopmans, R. (2010). Trade-offs between equality and difference: immigrant integration, multiculturalism and the welfare state in cross-national perspective, Journal of Ethnic and Migration Studies, 36 (1): 1-26, doi: https://doi.org/10.1080/13691830903250881

Kymlicka, W. (2003). Multikulturalno građanstvo: liberalna teorija manjinskih prava. Zagreb: Naklada Jesenski i Turk.

Kymlicka, W. (2007). Multicultural Odysseys: Navigating the New International Politics of Diversity. Oxford: Oxford University Press.

Mesić, M. (2006). Multikulturalizam. Zagreb: Školska knjiga

Miller, D. (2008). Immigration, nations and citizenship, The Journal of Political Philosophy, 16 (4): 371-390, doi: https://doi.org/10.1111/j.1467-9760.2007.00295.x 
Modood, T. (2007). Multiculturalism: a Civic Idea. Cambridge: Polity Press.

Murdie, R. A. i Borgegard, L. E. (1998). Immigration, spatial segregation and housing segmentation of immigrants in metropolitan Stockholm 1960-95, Urban Studies, 35 (10): 1869-1888, doi: https://doi.org/10.1080/0042098984196

OECD/EU (2015). Indicators of Immigrant Integration 2015: Settling In. Paris: OECD Publishing, doi: http://dx.doi.org/10.1787/9789264234024-en

Parekh, B. (2000). Rethinking Multiculturalism: Cultural Diversity and Political Theory. Houndmills - Basingstoke - Hampshire - London: Macmillan Press Ltd.

Parekh, B. (2008). Nova politika identiteta. Zagreb: Politička kultura.

Phillips, A. (1999). Which Equalities Matter? Cambridge: Polity Press.

Portes, A. i Zhou, M. (1993). The New Second Generation: Segmented Assimilation and Its Variants, The Annals of the American Academy of Political and Social Science, 530 (1): 74-96, doi: https://doi.org/10.1177/0002716293530001006

Raz, J. (1994). Multiculturalism: a liberal perspective, u: J. Raz (ur.). Ethics in the Public Domain: Essays in the Morality of Law and Politics. Oxford: Clarendon Press, 170-191, doi: https://doi.org/10.1093/acprof:oso/9780198260691.003.0008

Simon, P. (2012). French National Identity and Integration: Who Belongs to the National Community? Washington DC: Migration Policy Institute.

Taylor, C. (1994). The Politics of Recognition, u: A. Gutmann (ur.). Multiculturalism: Examining the Politics of Recognition. Princeton: Princeton University Press, 25-73.

Tempelman, S. (1999). Construction of cultural identity: multiculturalism and exclusion, Political Studies, 47 (1): 17-31, doi: https://doi.org/10.1111/1467-9248.00185

Walzer, M. (1994). Comment, u: A. Gutmann (ur.). Multiculturalism: Examining the Politics of Recognition. Princeton: Princeton University Press, 99-104. 


\title{
Multiculturalism in the European Context: Attainments and Disagreements
}

\section{Snježana Gregurović}

\begin{abstract}
SUMMARY
The paper deals with the normative meaning of multiculturalism and the idea of promoting cultural diversity through the politics of recognition, the politics of diversity and identity politics. The author wants to draw attention to the limited achievements and disagreements of multiculturalism with regard to the ways of including various cultural groups in society by exposing three multicultural theories - liberal multiculturalism, egalitarian multiculturalism and dialogically constituted multiculturalism. In the European context multicultural policies, as a state sponsored policies of integration, refer to the way in which countries respond to the cultural differences resulting from the increase of the number of immigrants. The countries' responses to these differences depend on the organization and structure of state institutions, the distribution of states' power and authority, and the manner of functioning of the welfare state (Geddes, 2003). Multicultural policies, as any other integration policies, should strive for immigrants to become equal citizens and to develop a sense of belonging to a host country. This paper examines how multiculturalist policies have been successful in achieving these goals.
\end{abstract}

Bearing in mind the fact that there is no integrative theory of multiculturalism that provides clear answers to questions related to the regulation of the cultural, religious and ethnic diversity, we have put forward three starting points of multicultural theory in order to indicate the variety of disputes that arise around these issues in modern liberal societies. Many liberal and even progressive thinkers believe that meaningful multiculturalism must be based on the equality policy, economic redistribution and social restructuring (Fraser, 1997), which is quite in line with the aim of the integration policy, that is equal treatment of immigrants in the host society and development of a sense of belonging among them. In the debate on multiculturalism there is a particularly pronounced gap when it comes to the idea of economic redistribution. On the one hand, the emphasis is on the idea of recognition of cultural differences without a call for economic redistribution, and on the other the issue of recognition is neglected in favour of economic redistribution. A more comprehensive conception of multiculturalism would require elimination of such contradiction (cf. Hartman and Gerteis, 2005), and the one-dimensional concept should be replaced with the integrative concept that includes both politics - politics of recognition and of economic redistribution.

The multiculturalist policies in Europe have been criticised from all sides. Criticism of multiculturalism has wide repercussions in various spheres of society and, among other things, it is a new impetus to extreme political parties that advocate a restrictive immigration policy as well as limited access to citizens' rights. The politicians of the three most powerful European economies (Germany, Great Britain and France) have taken a strong stance against multiculturalism and allegedly poor integration effects of multiculturalist policies as well as for disintegration of society. This understanding implies a static concept of social order in which cultural diversity is perceived as a threat to social cohesion. In this opinion, social order and stability 
are always much more difficult to achieve and maintain in the context of diversity than in the context of homogeneity. Besides, in the European context, questioning of multiculturalist approach and a certain return of assimilation (theory and politics) could be also found in the work of the United States theorists who try to justify such policies considering them as a strong platform which reduces the structural inequalities (Glazer, 1993; Portes and Zhou, 1993; Alba and Nee, 2003).

It is doubtful how much the reintroduction of assimilation policies in the European context would achieve the desired integration results. It seems that the introduction of any radical solutions referring to the inclusion of newly arrived groups produces very poor integration effects. Forcing cultural assimilation by state institutions through the introduction of obligatory integration courses and through giving importance only to socio-economic dimension could be just as deflating as the granting of special cultural rights and recognition of cultural difference through multiculturalist policies and ignoring importance of socio-economic dimension of integration.

Since recently there have been discussions about the connections between the politics of recognition and the politics of redistribution, it could be assumed that the multiculturalism backlash stems from economic rather than ideological reason. However, research findings do not confirm that the introduction of multiculturalist policies affects the weakening of the welfare state. But, on the contrary, there are findings that show how multiculturalism policy combined with generous welfare state could cause poor integration outcomes.

Many theoretical research (Banting and Kymlicka, 2004; Banting et al., 2006; Entzinger, 2006; Evans, 2006; Kraus and Schönwälder, 2006; Miller, 2008) question the connections between ethnic diversity, multiculturalism and the welfare state. However, there are few studies that explain how multicultural policies linked with generous welfare state influence immigrant integration. The findings of many studies dealing with the influence of multicultural policies on the welfare state suggest that the very multicultural policies are not responsible for the weakening of the welfare state and for reducing the allocation of funds for social purposes (Banting and Kymlicka, 2004; Banting et al., 2006; Evans, 2006; Entzinger, 2006; Miller, 2008). In the study of twenty-three types of multiculturalist policies, Banting et al. (2006) tested whether countries with more developed multiculturalist policies faced impoverishment and erosion of the welfare state in comparison with the countries in which these policies were less developed. It has been found that multiculturalism policies did not affect either the impoverishment or weakening of the welfare state, and even the number of immigrants, national minorities and indigenous people did not affect the welfare state and its functioning although it seemed that a sharp rise in the immigrant population affected the distribution of social resources.

Entzinger (2006) presented interesting findings about the retreat from the proclaimed multiculturalism as official national policy in the Netherlands trying to explain whether the abandonment of the multiculturalist policies caused a weakening of the welfare state, which occurred due to the generous funding of minorities and migrant groups. He concluded that a certain shift from multiculturalism policies was not a consequence of the weakening of the welfare state but because these policies failed to integrate minorities into socio-economic sphere of Dutch society. The results of several cross-national analyses suggest (Murdie and Borgegard, 1998; Phillips, 1999; Koopmans, 2010) that multiculturalist policies have failed to integrate immigrants particularly with respect to socio-economic terms. A large number of migrants con- 
tinue to be dependent on social assistance, they have a low employment rate and high unemployment, live in poor housing conditions, their children have a lower level of education and high school dropout rate, they are spatially segregated and their quality of life is worse than that of the natives. Ruud Koopmans (2010) also provides a similar argument about the retreat of "multicultural" policy approaches in the Netherlands. Analysing integration policies and the welfare-state regime in eight European countries Koopmans claims that multicultural policies, when joined with a generous welfare state, have resulted in low immigrant integration outcomes. These outcomes refer to low levels of labour market participation, high levels of segregation and a high crime rate among immigrants.

Koopmans (2010) argues that in the countries with a generous welfare state, multiculturalism may not be beneficial for all immigrants because it can lead to dependence on the welfare-state support and consequently to the increase of social and economic marginalization (Koopmans, 2010: 2).

Multiculturalist policies in the European context have failed as indicated by unsatisfactory integration results. The policies in the Netherlands, Sweden and Belgium, for example, have allowed migrants to survive on the welfare support without their inclusion in the labour market. It affected their economically disadvantageous position and further marginalisation.

At the end of the paper the normative reasons for preserving cultural and ethnic diversity are questioned. What if traditional values and preserving culture are not of crucial importance for a "good life" as multicultural theorists claim, but are also brought into question? As Barry (2006: 78) pointed out, birth or belonging to a particular ethnic group did not oblige anyone to be a guardian of their "ancestral culture." Finally, it should be noted that immigrants are not a homogenous group as Parekh (2008) pointed out. They differ among themselves with regard to the level of education, lifestyles, ethnic and/or religious affiliation, social capital, etc. In studying and making immigrant integration policies it should be kept in mind.

KEY WORDS: multiculturalism, multiculturalist policies, liberalism, immigrants, welfare-state, integration outcomes, European countries 